\title{
РОЛЬ ОСОБИСТОСТІ ПЕДАГОГА У ПРОЦЕСІ ФОРМУВАННЯ ОСОБИСТОСТІ МОЛОДШОГО ШКОЛЯРА
}

У даній статті викладено основний зміст науково-педагогічного дослідження, пов'язаного з вивченням проблеми взаємозв'язку особистісних якостей учителя та прочесу формування особистості його учнів.

Актуальність дослідження визначається важливістю такого аспекту педагогічної взаємодії як вплив особистості вчителя молодших класів на формування особистісних якостей дітей молодшого шкільного віку, на формування соціально прийнятних навичок, набутих дітьми під керівництвом педагога. Ураховуючи особливі відносини педагогів із дітьми молодшого шкільного віку, а саме наслідування поведінки дорослих, бажання демонструвати схвалювані педагогом вчинки, ми звертаємо увагу на особистісні особливості педагогів, їх психологічне здоров'я.

У нашій статті ми намагаємося довести, що особистість педагога має вплив на формування особистості дитини, який можна спостерігати в якостях особистості учнів, які найбільш часто будуть зустрічатися в даному класі $i$ відповідатимуть основним рисам особистості вчителя даного класу.

Ми вважаємо, що враховуючи велику кількість часу, яку діти проводять зі своїм учителем у період активного формування їх особистості, основним об'єктом для наслідування поведінки та характеру спілкування є саме вчитель.

Ключові слова: учитель початкових класів, учень молодших класів, емоційний стан, емочійний клімат.

Постановка проблеми. На наш погляд, вивчення аспекту спілкування вчителів та дітей $є$ особливо важливим, оскільки з огляду на особливі стосунки між учителями та дітьми молодшого шкільного віку, які взаємодіють із дорослими, засвоюють поведінку, спілкування шляхом наслідування, що передає характер і особливості поведінки дорослих, а саме імітуючи поведінку дорослих, прагнення продемонструвати дії, схвалені вчителем, ми звертаємо увагу на особистісні особливості вчителів та їх психічне здоров'я.

У дитинстві закладається основа моральних принципів, формуються соціально-психологічні характеристики особистості, тому для нас особливо важливо вивчати особистість педагога як засіб соціально-психологічного впливу на формування ціннісних особистісних якості дитини.

Аналіз актуальних досліджень. Проблему педагогічного спілкування вивчали Б. Г. Ананьєв, А. Л. Бодальов, Я. Л. Коломинский, М.І.Лісіна, 
А. А. Леонтьєв, Т.А.Рєпіна та інші видатні вітчизняні психологи. Не дивлячись на те, що цю тему досліджувала велика кількість вітчизняних і зарубіжних психологів і педагогів, вона все одно звертає на себе велику увагу, оскільки процес розуміння і усвідомлення важливого аспекту педагогічної взаємодії: особистості вчителя молодших класів, яка має великий вплив на формування особистісних якостей дітей молодшого шкільного віку, на формування соціально прийнятних навичок, набутих дітьми під керівництвом педагога, завжди була, є і буде актуальною.

Значущість дослідження полягає в тому, що ми дослідили взаємозв'язок між рівнем розвитку особистості вчителя та формуванням рівня особистісних якостей у дитини молодшого шкільного віку. Отримані результати дають змогу розширити уявлення про специфіку процесу спілкування між викладачем та молодшим школярем. Провели більш комплексне соціально-психологічне дослідження особистості вчителів, розширивши теоретичне розуміння специфіки професії вчителя початкової школи.

Мета і завдання дослідження. Вивчити взаємозв'язок між особистісними якостями вчителя та ступенем сформованості особистісних якостей у дітей в класі. Ми намагаємось довести, що особистість учителя має значний вплив на формування особистості дитини.

Ми вважаємо, що враховуючи чудовий час, проведений дітьми зі своїм учителем під час активного формування їх особистості, учитель $\epsilon$ головним прикладом для наслідування поведінки та способів спілкування.

Завдання нашого дослідження полягає в поглибленому аналізі наукової літератури, що розширює теоретичне розуміння особливостей професії; доведення важливості ролі особистості вчителя у формуванні особистості учня початкових класів.

Методи дослідження. Під час дослідження було використано три види тестових завдань, розроблених відомими вітчизняними й зарубіжними педагогами та психологами.

Першим був проведений тест за опитувальником К. Томаса «Визначення способів регулювання конфліктів». Наступний - діагностика стилю педагогічного спілкування - методика, розроблена І. В. Нікішиною. І останній - уміння організувати свою работу - тестовий примірник, розроблений Н. Д. Левітовою.

Виклад основного матеріалу. Структура особистості вчителя включає такі характеристики, як орієнтація та мотивація (соціальна, когнітивна, професійна - те, що тримає вчителя в цій професії). Особистість визначають 
і педагогічні здібності, що забезпечують успішне виконання роботи (Нові технології навчання, 2005).

Останнім часом розмежовують дві широкі групи педагогічних навичок: перцептивні, тобто антропологічні, пов'язані з розумінням іншої людини, та управлінські, які лежать в основі впливу на людину. На особисті прояви вчителя впливає його характер, темперамент, психічні стани, у тому числі й тимчасові. До узагальнених характеристик належить індивідуальний стиль педагогічної взаємодії вчителя з учнем, під яким розуміють стійке поєднання завдань, засобів та методів діяльності та спілкування вчителя, що визначається його психофізіологічними особливостями та попереднім досвідом (Чудновский, 1981).

Важливим моментом професійно-педагогічної підготовки є особисті якості вчителя, які привернули увагу П. Ф. Каптерева. Дослідники відзначають такі якості, як цілеспрямованість, наполегливість, працьовитість, скромність, спостережливість, контактність. Особливо важливими є такі характеристики вчителя, як готовність розуміти психічні стани учнів та емпатія, а також необхідність соціальної взаємодії. Велике значення дослідники надають «педагогічному тактові», у прояві якого виражається загальна культура вчителя та високий професіоналізм його педагогічної діяльності й спрямованості. Учитель, як організатор навчальної діяльності студента, повинен мати такі професійні якості:

а) високий рівень професіоналізму;

б) об'єктивність оцінювання результатів навчання;

в) володіння педагогічними вміннями, що дозволяють організувати навчальний процес (Чудновский, 1981).

Н. В.Кузьміною, А.І. Щербаковим та іншими дослідниками були визначені основні функції вчителя: конструктивну, організаторську, комунікативну, гностичну).

Педагогічні навички відіграють важливу роль у становленні особистості вчителів:

1. Дидактичні навички - здатність передавати навчальний матеріал учням, робити його доступним для дітей, передавати їм матеріал чітко і зрозуміло, викликати інтерес до предмета та підтримувати активну самостійну діяльність учнів. Учитель зі сформованими дидактичними навичками здатний правильно реконструювати робочий матеріал у разі потреби, адаптувати його, важке робити легким, складне - простим (Нові технології навчання, 2005). 
2. Академічні навички - здатність працювати у відповідній галузі науки. Викладач знає предмет не тільки в межах курсу, але ширше та глибше, вільно володіє матеріалом, виявляє до нього інтерес та веде дослідницьку роботу.

3. Перцептивні навички - здатність проникати у внутрішній світ навчання, психологічне спостереження в поєднанні 3 тонкощами розуміння особистості учня та його тимчасових психічних станів. Учитель повинен за незначними ознаками, невеликими зовнішніми проявами вловити найменші зміни у внутрішньому стані учня.

4. Мовні навички - здатність чітко висловлювати свої думки та почуття за допомогою мови, міміки та пантоміми.

5. Організаційні навички - це, з одного боку, здатність організовувати учнівський колектив, об'єднувати його, надихати на вирішення важливих завдань, а з іншого - правильно організовувати власну роботу.

6. Навички спілкування - уміння спілкуватися з дітьми, уміння знаходити правильний підхід для учнів, уміння розвивати адекватні стосунки з ними з виховної точки зору, наявність виховного такту.

7. Педагогічна уява (або прогностичні здібності) - це особлива здатність, яка виражається в прогнозуванні наслідків дій учнів, у виховному проектуванні особистості учнів, пов'язаному з уявленням про те, що з учня вийде в майбутньому, у здатності прогнозувати розвиток певних здібностей.

8. Уміння розподіляти увагу одночасно між кількома видами діяльності має особливе значення для роботи вчителя. Досвідчений викладач ретельно стежить за змістом і формою викладу матеріалу, розвитком його думки (або думки учня), водночас тримає в полі уваги всіх учнів, чутливих до ознак втоми, неуважності, непорозуміння. Учитель має звертати увагу на всі випадки порушення дисципліни та стежити за власною поведінкою (позою, мімікою та ходою) (Бех, 2005).

Статистика свідчить, що понад 90 \% першокласників ходять до школи з великою радістю, але в третьому класі кожен десятий учень ходить до школи без задоволення, оскільки там у нього «не найкращі» стосунки $з$ однолітками. Організовуючи співпрацю, дружні стосунки між дітьми та окремими групами, можна сформувати згуртований колектив. Відносини дітей у класі формуються переважно за допомогою вчителя. Учитель завжди виділяє окремих учнів у класі як зразок для інших у навчанні та поведінці, при цьому звертаючи увагу на недоліки в поведінці інших учнів. Як правило, більшість дітей початкової школи відтворюють у своєму ставленні до них ставлення вчителя, який ще недостатньо обізнаний із 
критеріями оцінки певних учнів. Активність та самопочуття дитини залежить від стилю взаємин учня та вчителя.

Згуртованість у класі починає формуватися з перших шкільних днів. Дослідження показують, що майже всі діти в цей час використовують певне уявлення про ідеал. Цей ідеал $є$ більш ніж розмитим, але він також відіграє важливу роль у механізмі учнів до навчання. Однак, через деякий час ставлення деяких дітей до школи змінюється.

Щодо вчителів, які не можуть налагодити нормальні стосунки зі своїми дітьми, деякі учні класу починають виявляти байдужість до школи через три-чотири місяці, у дітей зникає бажання навчатися. Основною причиною цих негативних явищ $€$ недосконалість організації вчителів навчально-виховного процесу.

У положенні про середню загальноосвітню школу України зазначено, що повсякденне адміністрування виховної роботи в класі здійснює класний керівник. Він відповідає за вирішення таких завдань: навчання учнів культурі поведінки, формування в них високих моральних якостей; забезпечення узгодженості освітніх потреб між сім'єю та школою; проведення заходів щодо зміцнення здоров'я учнів; організація суспільно корисної роботи учнів, ведення класної документації; побудова демократичних відносин із учнями та їх батьками, спільна робота, сприяння розвиткові учнівського самоврядування.

Отже, шкільне життя включає взаємодію між учнями та вчителями. Взаємовідносини між викладачами та учнями - їх взаємини на уроках, i поза ними, ніколи впливає не лише на процес навчання, а формулює ставлення учнів до школи та визначають стосунки учнів із однокласниками (Коваленко та Бєлкіна, 2006).

Виникнення та успішний розвиток міжособистісного спілкування можливе лише за умови взаєморозуміння між учасниками процесу. Найважливішу роль у цьому процесі відіграє професіоналізм учителя та атмосфера навчання, яку вчитель створює в класі та не тільки. Усе це тісно пов'язано з характером і стилем стосунків учитель - учень та їх безпосереднім спілкуванням. Учитель початкових класів та діти - єдиний «організм» взаємовпливу. Подібний «феномен» виникає двічі в житті кожної людини: у момент народження і під час першої зустрічі з учителем і школою (Коваленко та Бєлкіна, 2006).

Галасливий або дратівливий учитель, який не хоче, який не може стримувати себе, який негативно впливає на психічне самопочуття та практичну діяльність дітей, породжує в них негативні переживання, стан 
тривожних очікувань, невпевненість у собі, страх. У такого вчителя діти залякані, нерішучі, голосні та грубі у взаєминах між собою; вони часто скаржаться на нездужання та настрій, біль у серці та шлунку, головний біль.

3 одного боку, учитель повинен знати і слідувати загальній меті педагогічного процесу. 3 іншого боку, він повинен брати активну участь у створенні психологічного мікроклімату класу. Завдання вчителя організувати колективну діяльність дітей таким чином, щоб вони відчували комфорт і гармонію в соціальному оточенні.

Аналіз літературних джерел свідчить про те, що від міри вираженості в педагога трьох проаналізованих параметрів, а саме, «домінуванняпасивність», «симпатія - антипатія» або «доброзичливість - ворожість», «формальність - особистість», і залежать його стосунки з учнем, емоційний мікроклімат у групі, і, відповідно, згуртованість класу та ефективність педагогічної взаємодії в цілому. Від вираженості цих параметрів також також залежить, який педагогічний стиль спілкування переважає в учителя: демократичний, авторитарний чи ліберальний. Викладачам із демократичним стилем педагогічного спілкування легко вдається налагодити контакти з учнями, вони емоційно стійкі і можуть адекватно реагувати на конфліктні ситуації в процесі педагогічної діяльності.

Учитель із демократичним стилем спілкування легко об'єднати учнів та залучає всіх до активної участі у спільних заходах, які за своєю формою дають учням відчуття спільності та значущості у шкільному соціумі. У свою чергу, учитель із авторитарним стилем педагогічного спілкування характеризується низьким рівнем комунікабельності, рухливістю емоційної сфери та нездатністю конструктивно вирішувати психолого-педагогічні проблеми в процесі навчальної роботи.

Це створює несприятливий психологічний клімат, пригнічує ініціативу та відповідальність, розвиває невпевненість у дітей та створює нижчий рівень згуртованості колективу класу (Бех, 2005).

у процесі дослідження було використане тестування як метод наукового дослідження, тестові завдання передбачають отримання інформації про психологічні особливості викладачів та учнів на основі аналізу успішності певних предметів. Випробуваному пропонується виконати перелік завдань. Кількість виконаних завдань $€$ основою для визначення наявності чи відсутності, а також ступеня розвитку в досліджуваного певної психологічної якості.

Тест за опитувальником К. Томаса «Визначення способів регулювання конфліктів» дав такі результати: у результаті аналізу 
відповідей учнів і вчителя одного класу було виявлено, що $60 \%$ учнів, як і вчитель, мають схильність до співпраці.

Відповідно до другої шкали психоемоційного стану, у вчителя виявлено стійкий емоційний стан, разом із учителем благополучний психоемоційний стан виявлено у $89 \%$ учнів.

Аналіз результатів тесту на вміння організувати свою роботу виявив такі результати: учитель набрав загалом 24 бали, виявивши гарний рівень, 88 \% учнів, у свою чергу, набрали від 19 до 22 балів, що свідчить про достатній рівень сформованості навичок самоорганізації і вміння планувати свій день.

Аналіз отриманих результатів дає можливість говорити про те, що наша гіпотеза підтвердилася і сформовані особистісні якості дитини молодшого шкільного віку обумовлені особистісними особливостями педагога.

Отже, у класах, де працює емоційний, творчий учитель, схильний до демократичного стилю спілкування, із відносною стабільним настроєм, упевнений у собі, ініціативний, здатний до співпереживання, спокійний, із конструктивною тривожністю, відкритий до інновацій, прислуховується до думки дітей, доброзичливий до оточуючих, рівень формування особистості дитини буде більш високим і сприятливим.

Висновки та перспективи подальших наукових розвідок. У молодшому шкільному віці відбувається становлення дитини як особистості, що створює її суспільну спрямованість, формує навички соціальної поведінки та інші загальнолюдські цінності. Важливу роль школа відіграє в розвиткові особистості молодшого школяра, включаючи процес спілкування педагога з учнем.

Постійна участь у спілкуванні з дітьми протягом робочого дня вимагає від учителя великих нервових та психічних витрат, емоційної стійкості, терпіння й контролю над зовнішньою поведінкою. Процес навчання та виховання постійно здійснюється під час безпосереднього контакту з дітьми.

У дитинстві встановлюються основні моральні принципи, формуються соціально-психологічні характеристики особистості, тому для нас особливо важливо вивчати особистість педагога як засіб соціально-психологічного впливу на формування цінних особистісних характеристик дитини.

Суб'єктивно особистість для будь-якої людини сприймається як його Я (як образ Я). Прагнути бути особистістю - означає прагнути до соціально значимої діяльності.

Зі вступом до школи змінюється весь лад життя дитини, змінюється режим, складаються певні відносини з оточуючими людьми, перш за все, з учителем. 
Якщо навчальна діяльність і життєдіяльність дитини в цілому побудовані з урахуванням мотиваційної сфери, а значить, і з урахуванням формування спрямованості особистості. Правильно організоване виховання невіддільне від природного перебігу життєдіяльності людини. Ось чому кажуть, що гарне виховання там, де його не видно.

\section{ЛІТЕРАТУРА}

Бех, І. Д. (2005). Виховання особистості. Київ: Либідь (Bekh, I. D. (2005). Personality education. Kyiv: Lybid).

Нові технології навчання (2005). Київ: Наук.-метод. центр вищої освіти (New learning technologies (2005). Kyiv).

Коваленко, Є. І., Бєлкіна, Н. І. (2006). Історія зарубіжної педагогіки (Kovalenko, Ye. І., Bielkina, N. I. (2006). History of foreign pedagogy. Kyiv).

чудновский, В. Є. (1981). Нравственная устойчивость личности. М.: Педагогика (Chudnovskyi, V. Ye. (1981). M oral sustainability of the personality. M.: Pedagogy).

Левківський, М.В.(2006). Історія педагогіки. Киів: Центр навчальної літератури (Levkivskyi, M. V. (2006). History of pedagogy. Kyiv: Center for Educational Literature).

\section{PEЗЮME}

Скоромная Марианна. Роль личности учителя в процессе формирования личности школьника младших классов.

Эта статья отображает основное содержание научно-педагогического исследования, связанного с изучением проблемы взаимосвязи личных качеств учителя и процесса формирования личности его учеников.

Актуальность исследования определяется важностью такого аспекта педагогического взаимодействия, как влияние личности учителя на формирование личных качеств детей младшего школьного возраста, формирование социально приемлемых навыков, приобретенных детьми под руководством учителя. Учитывая особые отношения учителей с детьми начального школьного возраста, а именно имитацию поведения взрослых, желание продемонстрировать одобренные учителем действия, мы обращаем внимание на личные характеристики учителей, их психологическое здоровье.

В своей статье мы пытаемся доказать, что личность учителя влияет на формирование личности ребенка, что можно наблюдать в качествах личности учеников, которые чаще всего встречаются в этом классе и соответствуют основным личностным качествам учителя этого класса.

Мы считаем, что, учитывая большое количество времени, которое дети проводят со своим учителем в период активного формирования их личности, основной целью учителя является следование поведению и природе общения.

Ключевые слова: учитель начальных классов, ученик младших классов, эмоциональное состояние, эмоциональный климат

\section{SUM M ARY}

Skoromna Marianna. The role of the personality of the teacher in the process of forming the personality of the junior pupil.

This article contains the main content of the scientific and pedagogical study related to elaboration of the problem of the relationship of personal qualities of the teacher and the process of personality formation of his students.

The relevance of the study is determined by the importance of such aspect of pedagogical interaction as the influence of the personality of the junior teacher on the 
formation of personal qualities of children of primary school age, formation of socially acceptable skills acquired by children under the guidance of the teacher. Given the special relationship of teachers with children of primary school age, namely imitation of adult behavior, the desire to demonstrate the actions approved by the teacher, we pay attention to the personal characteristics of teachers, their psychological health.

In our article we try to prove that the personality of the teacher has an impact on the formation of the child's personality, which can be observed in the qualities of the personality of students who will most often be found in this class and correspond to the main personality traits of the teacher of this class.

We believe that given the large amount of time that children spend with their teacher during the period of active formation of their personality, the main object to follow the behavior and nature of communication is the teacher.

Key words primary school teacher, primary school pupil, emotional state, emotional climate.

\section{Удк 378}

Валентина Швиденко

Заступник директора з виховної роботи

Першої міської гімназії м. Черкас ORCID ID 0000-0002-3207-4384

DOI 10.24139/2312-5993/2020.08/391-398

\section{ТЕОРЕТИЧНІ ОСНОВИ СИСТЕМИ ВИХОВНОЇ РОБОТИ У ВІТЧИЗНЯНОМУ НАУКОВОМУ ДИСКУРСІ}

У статті проаналізовано праці видатних вітчизняних науковців. Висвітлено їх погляди на систему виховної роботи. Розкрито процес формування виховного впливу колективу на особистість, взаємозв'язок виховання і вивчення особистості дитини, колективу та особистості, навчання і виховання. Доведено, що естетичне виховання як неперервний прочес має здійснюватися передусім у діяльності, у різнобічній соціальній творчості. Окреслено сутність виховного процесу як сходження особистості до морально-духовних цінностей, теоретичні підходи до проблеми готовності майбутніх учителів початкової школи до творчої навчально-виховної діяльності.

Ключові слова: виховна робота, педагог, школа, діти, колектив, освітній процес.

Постановка проблеми. У даний час у нашій країні актуалізується проблема виховання підростаючого покоління. Національна стратегія розвитку освіти в Україні на період до 2021 року підкреслює важливість виховання як цілеспрямованого впливу на дітей. Стратегічні установки держави націлюють педагогічну науку і практику на відновлення виховання як специфічного напряму роботи з дітьми, на оновлення виховного процесу в різних соціальних інститутах, i, перш за все, в закладах освіти (Національна стратегія розвитку освіти в Україні на період до 2021 року, 2017). 